\title{
Trends in office rents in the City of London: 1867-1959
}

Article

Accepted Version

Devaney, S. (2010) Trends in office rents in the City of London: 1867-1959. Explorations in Economic History, 47 (2). pp. 198-212. ISSN 0014-4983 doi:

https://doi.org/10.1016/j.eeh.2009.11.001 Available at https://centaur.reading.ac.uk/29412/

It is advisable to refer to the publisher's version if you intend to cite from the work. See Guidance on citing.

Published version at: http://www.sciencedirect.com/science/article/pii/S0014498309000552

To link to this article DOI: http://dx.doi.org/10.1016/j.eeh.2009.11.001

Publisher: Elsevier

All outputs in CentAUR are protected by Intellectual Property Rights law, including copyright law. Copyright and IPR is retained by the creators or other copyright holders. Terms and conditions for use of this material are defined in the End User Agreement.

\section{www.reading.ac.uk/centaur}

\section{CentAUR}

Central Archive at the University of Reading

Reading's research outputs online 


\section{Trends in Office Rents in the City of London: 1867-1959}

Published by Elsevier in Explorations in Economic History, 47 (2): 198-212. doi:10.1016/j.eeh.2009.11.001

Author:

Steven Devaney

Affiliation:

University of Aberdeen Business School

Address:

University of Aberdeen Business School

Edward Wright Building

Dunbar Street,

Aberdeen

AB24 3QY

Acknowledgements:

This paper has its origins in doctoral research carried out at the University of Reading, with financial support at various stages from the Reading Real Estate Foundation, Jones Lang LaSalle and the University of Aberdeen. It was first presented at the New Researchers Session of the Economic History Society Annual Conference 2009. It has subsequently benefited from the detailed critique by the anonymous reviewers for this journal, which has resulted in a better paper. The author would also like to thank his supervisors, Michael Ball, Colin Lizieri and Neil Crosby, as well as Peter Scott and Rainer Schulz for their comments at various points. The help of staff at the Guildhall Library during data collection is acknowledged. Any remaining errors are the author's sole responsibility. 


\title{
Trends in Office Rents in the City of London: 1867-1959
}

\begin{abstract}
This paper details the construction and analysis of a dataset of office lettings, which is used to produce a rent index for the City of London spanning the late nineteenth and early twentieth centuries. It advances prior research through application of a modern version of the repeat measures technique and in coverage of years where office rents have not been previously measured. Results show that there has been no real growth in rents over the period as a whole. However, there have been distinct phases of rental growth and decline that correspond with the wider economic fortunes of the City.
\end{abstract}

Keywords: City of London, Offices, Rent index, Repeat measures regression

\section{Introduction}

The City of London is home to one of the largest and most established office markets in the world, the operation of which contributes significantly to the functioning of this location as a financial and commercial centre. Hence, its operation and performance over recent decades has been extensively studied. ${ }^{1}$ However, in contrast to other aspects of the City and its economy, knowledge about the history of its office market is limited. Several studies have explored physical and architectural aspects, particularly in relation to the emergence of the purpose built office block upon the City's landscape and the gradual displacement of other, competing land

\footnotetext{
${ }^{1}$ For a review, see Lizieri (2009), especially Part II.

(C) 2010. This manuscript version is made available under the CC-BY-NC-ND 4.0 licence http://creativecommons.org/licenses/by-nc-nd/4.0/
} 
uses. ${ }^{2}$ Yet few have sought to explicitly examine the rents or prices of office buildings over time, an omission that this paper seeks to rectify with respect to rents.

The renting of office space in the City is by no means a recent phenomenon. It is true that the emergence of the office is most closely associated with the growth in the nineteenth century of the insurance companies and joint stock banks, who constructed office buildings in central London for their own occupation. ${ }^{3}$ However, not only did these organisations often let surplus space in their buildings to other companies, ${ }^{4}$ but, from the 1840s, some office blocks were being built on a completely speculative basis by groups of investors for either sale or letting. ${ }^{5}$ This led by the 1860 s to the formation of private property companies to develop and rent office buildings. ${ }^{6}$ It is the records of such property companies that are used in this study to explore trends in office rents from the mid nineteenth to the mid twentieth century.

The period covered by this research was one of profound change in the City of London. ${ }^{7}$ At the beginning, the City contained a mixture of commercial, financial and manufacturing activities and still had a sizeable residential population. Over the following decades, though, changes in transport and land values led first to decline in the resident population and then later to relocation of other uses for which a central site was no longer essential. These processes culminated in a much changed City by

\footnotetext{
${ }^{2}$ For examples, see Keene (1997) and Summerson (1990).

${ }^{3}$ Summerson (1990).

${ }^{4}$ Noted by Summerson (1990), whilst Black (2000) gives specific examples.

${ }^{5}$ In fact, the earliest cited example is a block built in 1823 in Clement's Lane (L'Anson, 1864: 25), whilst another, well documented example is Royal Exchange Buildings, built 1844-5, on which see Jefferson Smith (1997).

${ }^{6} \operatorname{Scott}(1996: 22-23)$.

${ }^{7}$ See, in particular, overviews in Dunning and Morgan (1971), chapter 1, and Michie (1992), chapter 1.

(C) 2010. This manuscript version is made available under the CC-BY-NC-ND 4.0 licence http://creativecommons.org/licenses/by-nc-nd/4.0/
} 
the end of the period where offices were the predominant land use and finance was the main economic activity. The series developed here indicates the changing fortunes of the City office market over this important time frame and how rental trends developed in response to long term shifts in the demand for and supply of office space.

The paper now proceeds as follows. In the next section, a review takes place of other studies that have explored historical trends in commercial property rents. This is followed by discussion of the rent data used in this study and its sources. Section four explains the method adopted for estimation of an office rent series before section five presents the rent index itself, setting its trends in the context of economic conditions over the period concerned. Given the mix of activities within the City over much of its history, the question arises as to whether a single rent series is appropriate or whether offices in different areas might have displayed different trends. Therefore, this issue is considered in section six. A final section then concludes.

\section{Previous literature on commercial rents}

Within the literature on historical urban development, studies that trace the rents or prices of commercial property over the long run are rare, despite the importance of these building types in recent history. For the United States, Wheaton, et al. (2009) have provided evidence on price movements in the New York office market through the twentieth century, whilst Kaiser (1997) draws upon a variety of earlier studies on different US cities to analyse property investment income and returns from the 1920s. Meanwhile, Scott (1996) compiles data on property investment in the UK from 1920 and this primarily reflects commercial real estate assets.

The particular focus of this review is historical data on commercial property rents in the UK, especially in relation to offices. However, tracking the prices or rents of 
commercial properties is not a straightforward process. Buildings are heterogeneous and they may also vary in quality over time, making the use of average prices or rents unreliable. Furthermore, trading occurs within a private market, and both sales and lettings are irregularly spaced in time, although the latter are typically more frequent than the former. To overcome these difficulties, it is common to use either valuation based indices or transaction based techniques that control for quality and transaction timing.

With regard to the former, a problem arises in that regular valuations of property assets prior to the 1960s were unusual, with one major exception. That exception was valuation for the purpose of taxation, which was made on a rental basis. ${ }^{8}$ It is from taxation statistics that Feinstein (1988) constructed a rent series for the combined category of industrial and commercial buildings over the period 1850-1920. This series relates to England and Wales. Otherwise, rateable values have been used more generally to comment on changing property values over time. ${ }^{9}$

For the study of offices, their aggregation with other property types in both the Feinstein series and other rateable value statistics is unhelpful. ${ }^{10}$ However, even if this were not the case, the Feinstein series is problematic for two reasons. First, although the rent index is presented at an annual frequency, the underlying tax valuations took place at three to five year intervals. Second, it is only from 1873-1910 that separate trends for the industrial and commercial category can be distinguished. For other

\footnotetext{
${ }^{8}$ Predominantly, this was for local taxation (rating), but valuations were also used for Schedule A Income Tax purposes.

${ }^{9}$ In the case of the City, examples are Keene (1997: 268-9) and Dunning and Morgan (1971: 50).

${ }^{10}$ Offices did not appear as a separate land use within rating publications until after the Second World War, at which point valuations for taxation are less frequent.

(C) 2010. This manuscript version is made available under the CC-BY-NC-ND 4.0 licence http://creativecommons.org/licenses/by-nc-nd/4.0/
} 
years, the rent series is extrapolated using the change in values of all buildings, including dwellings.

Other than this, two series exist that track UK commercial property rents prior to the Second World War. One of these, by Crosby (1988), is for shop property in the city of Nottingham and covers the period 1910-1986. The other is by Turvey (1998). He studied rents in the City of London office market over the period 1869-1910, as well as levels of vacancy for a shorter period within that time frame. Thus, this latter study is of particular interest here in terms of its methods, sources and the results that were found.

To construct his index, Turvey used information that was recorded in the board minutes of the City Offices Company. This company owned several office blocks in the City, which were subdivided into a large number of rooms and let to many different tenants. However, comparison of their board minutes with other company records in the course of this research suggests that the former are problematic as a source of evidence on lettings. In particular, the minutes sometimes report rents that were in the course of negotiation rather than the final amount agreed with particular tenants, whilst, as Turvey (1998: 57) also notes, the space for larger lettings was not always well described.

From these minutes, Turvey identified rooms where two or more lettings had taken place. Using pairs of rents, he then applied the repeat measures regression procedure of Bailey, et al. (1963) to estimate annual rental changes. From this, Turvey produced interesting results that suggest that office rents increased in real terms over the late Victorian and Edwardian periods, despite periodic building booms that took place. These results are later compared with those from the series produced here, for which the data sources are now described. 


\section{Sources and description of data}

The dataset used in this study has been compiled from the rent rolls, deed books and lease registers of five property investment companies whose archives are held at the Guildhall Library in London. Some of these companies invested predominantly in offices whilst others owned a mixture of office, retail and residential assets. ${ }^{11}$ In all cases, the geographical focus was the London area. For this research, only lettings of offices situated in the City of London, as defined by its administrative boundary, were recorded.

The approach adopted was to record all available information relating to each letting. As a minimum, this consisted of the annual rental amount, the name of the tenant, the date on which the lease either commenced or was signed, and the office number or short description of the space being let. For a subset of transactions, more detailed information, such as the length and terms of the lease agreement, was also available. However, the minimum data characterises $72 \%$ of the dataset and this was an important factor in the selection of an index construction method.

The names of the companies, together with the number of City office assets that they owned and the number of transactions obtained from their records, are listed in Table $1 .{ }^{12}$ It is immediately apparent from the table that there are many more lettings than assets. This is not only because of time, but also because most of the buildings were let to several tenants at once.

\footnotetext{
${ }^{11}$ Biographical information on the City Offices Company is given in Turvey (1998) and Scott (1996), for the Gresham House Estate Company by Burnand (1957) and for Consolidated London Properties and City \& West End Properties by Broackes (1979).

${ }^{12}$ Document references are for the manuscript numbers given in the Guildhall Library catalogue.

(C) 2010. This manuscript version is made available under the CC-BY-NC-ND 4.0 licence http://creativecommons.org/licenses/by-nc-nd/4.0/
} 


\section{INSERT TABLE 1}

For creating an index, it is important to consider whether or not the dataset is representative of the City office market as a whole. In terms of location, the 51 assets are spread throughout the City and this enables spatial disaggregation of the results in section six. However, in age, nearly all of the buildings date from the Victorian and Edwardian periods. This raises the question of whether rent observations from these assets will be representative of the market in later years.

Reference to literature on the City's physical development suggests that this age profile does remain typical for much of the period being studied. For instance, Ball (1996) notes that, between the Edwardian building boom and the early 1950s, there was only a limited amount of office construction in London and the adoption of new construction technologies was slow. Meanwhile, evidence from other records of these companies shows that not only were the properties maintained over time, but they were also periodically refurbished in order to keep them competitive. ${ }^{13}$ With the onset of the postwar building boom, though, the comparative quality of the sample assets is likely to have weakened.

In respect of the lettings, although the total number in Table 1 appears large, the observations are not evenly distributed through time. This is shown by Figure 1 where it can be seen that most data points fall in the period 1906-1960. The lack of earlier data may seem surprising given the comments on building age, but the distribution is also affected by the date coverage of the surviving records. Nonetheless, sufficient

\footnotetext{
${ }^{13}$ For the earliest built offices in the dataset, an example is the installation of lifts by the owners during the late Victorian period. See also Turvey (1998: 62).

(C) 2010. This manuscript version is made available under the CC-BY-NC-ND 4.0 licence http://creativecommons.org/licenses/by-nc-nd/4.0/
} 
data was available to present a rent index at an annual frequency from 1867 through to 1959.

\section{INSERT FIGURE 1}

To construct the index, the initial contract rent for each letting has been utilised, taking that figure to be a signal of market conditions in the year that the lease began. This rent was usually quoted as an annual amount, although the payment of rent was typically quarterly in arrears. Clearly, though, many factors will influence the level of rent, not least the size and specification of the space being let. Thus, ability to control for quality differences was another important factor in the choice of method.

One aspect that deserves particular attention is the role of lease terms. Since these govern the costs and commitments of both landlords and tenants, then variations in these terms should also contribute to differences in rent. However, the details of such terms are generally lacking in this dataset. Yet provided that there are no systematic changes in terms and conditions over time, then, whilst this may introduce error into index estimation, it should not lead to bias. Therefore, the question is whether, over this long period of interest, systematic changes to leasing practices did take place.

Some evidence on this can be gleaned from the subset of lettings for which more detailed information was available. This subset indicates stability in the terms of office leases for most of the period studied. This is quantified for the length of lease contracts in Table 2.

INSERT TABLE 2 
Table 2 shows only limited fluctuation in the average lease length over time. It can also be seen that the leases in this sample were quite short, at least in comparison with those documented elsewhere for shop properties. ${ }^{14}$ The most noticeable change in the table is between earlier decades and leases agreed during 1960-79. Further examination of the dataset suggests that this is continuation of a change that started in the 1950s and which encompassed lease length, the use of rent reviews and the nature of other lease terms.

Specifically, longer lettings for larger blocks of space became more common and with longer leases and persistent postwar inflation came more frequent inclusion of rent revision clauses to ensure that landlord rental income was protected in real terms. ${ }^{15}$ Meanwhile, responsibility for rates and other expenses increasingly passed entirely to the tenant, having been shared between landlords and tenants during the interwar years. ${ }^{16}$ These changes may influence the rent index in the 1950 s, although their full impact is mitigated by the terminus of the series at 1959 .

Finally, it should be stressed that individual rental transactions were needed for this research rather than just totals of the rent received by each company in each year. In any year, this latter figure would reflect both the rents on new leases and the rents prevailing on existing contracts agreed in different (earlier) market conditions. Total rent received would also be affected by the extent to which properties were vacant. For these reasons, it does not reflect the market rent level at different points in time

\footnotetext{
${ }^{14}$ Scott (1996) notes that shops let to multiple retailers were often on $99+$ year lease terms.

${ }^{15}$ The trend to larger lettings is likely to be connected with the growth in size of many City firms after the Second World War, on which see Kynaston (2001).

${ }^{16}$ This picture is consistent with that described by Rose (1985: 149) for office property.

(C) 2010. This manuscript version is made available under the CC-BY-NC-ND 4.0 licence http://creativecommons.org/licenses/by-nc-nd/4.0/
} 
and this explains why individual transactions are used in conjunction with the model outlined next.

\section{Index construction method}

The method selected for use in this research was the repeat measures regression technique first proposed by Bailey, et al. (1963) and subsequently extended by several other studies, notably those of Case and Shiller (1987) and Shiller (1991, 1993). The method has been widely used for modelling real estate prices and rents, ${ }^{17}$ but it has also been applied in other contexts. For instance, a recent article in this journal by Klovland (2009) applied the method to data on ocean freight rates.

One of the main advantages of the method is its parsimony in specification and data requirements, especially compared with hedonic regression. This is of particular use here where only limited supporting data exists for the majority of transactions in the dataset. The idea behind the method is to observe changes in rents for space that has let more than once. If no alterations are made to the space or the form of lease between lettings, then rent change should purely be a function of time plus a random error component, with no quality distortion. Hence, the aggregate change in rents over time can be estimated as follows:

$$
\ln \left(r_{i, t}\right)-\ln \left(r_{i, t-j}\right)=\beta_{2} D_{i, 2}+\beta_{3} D_{i, 3}+\ldots+\beta_{t} D_{i, t}+\ldots+\beta_{T} D_{i, T}+\varepsilon_{i, t}
$$

where $\mathrm{r}_{\mathrm{i}, \mathrm{t}}$ is the annual rent for office unit $i, \mathrm{r}_{\mathrm{i}, \mathrm{t}-\mathrm{j}}$ is the annual rent for a previous letting of that space $j$ periods earlier and $\mathrm{D}$ are dummy variables that take the value of -1 for

\footnotetext{
${ }^{17}$ Recent applications to the creation of long run historical series include Eichholtz (1997) and Wheaton, et al. (2009), in addition to Turvey (1998).

(C) 2010. This manuscript version is made available under the CC-BY-NC-ND 4.0 licence http://creativecommons.org/licenses/by-nc-nd/4.0/
} 
the period in which the first letting occurs, +1 where the second letting occurs, and 0 for any other period in each case. ${ }^{18}$ The coefficients on these dummies then capture the levels of a $\log$ rent index.

It may be noted that this model is essentially a fixed-effects model, estimating an index with reference to rent movements recorded for individual units. Thus, the need to explain cross-sectional variation in rent levels between units with different qualities is avoided. However, a key assumption in this framework is that of no change in each subject over the period between the two transactions. If this assumption is unlikely to hold, then estimates of the index are vulnerable to biases. To illustrate this, potential problems are as follows. First, if there was a tendency by landlords to merge rooms and create larger units over time, this would bias rent change upwards. Alternatively, if landlords not only maintained buildings, but enhanced their specification over time, this could also lead to upward bias, as subsequent rents would effectively be for better quality space.

Both of these scenarios are plausible, but their importance as issues also depends on the extent to which they can be observed and controlled for, either by not pairing lettings across such events or by the inclusion of additional variables in the model to capture their effect. ${ }^{19}$ In this study, despite a lack of precise room data on features such as floor area, a good knowledge of the properties could be obtained from the source documents and other company records, whilst room descriptions, though short, were often highly informative. As a result, important changes could normally be detected, with pairing avoided, but it is acknowledged that this process is unlikely to

\footnotetext{
${ }^{18}$ Note that no dummy is included for lettings in the first (base) period.

${ }^{19}$ Such 'hedonic repeat measures' models are discussed in Shiller (1993).

(C) 2010. This manuscript version is made available under the CC-BY-NC-ND 4.0 licence http://creativecommons.org/licenses/by-nc-nd/4.0/
} 
have been perfect, with, for instance, more minor, incremental improvements to units probably reflected in the results.

Further issues arise with the specification of the model shown above. ${ }^{20}$ First, it only estimates an equal-weighted index. Second, the logarithmic formulation of the dependent variable means that rent movements are underestimated. This is because it leads to computation of geometric rather than arithmetic averages of rental change in each period. ${ }^{21}$ This suggests that, in a rising market, index estimates will be biased downwards, whilst in falling markets, they will be biased upwards. The effects of this could potentially be severe when estimating a long historical series, although an expost adjustment for such biases was suggested by Goetzmann (1992).

Third, OLS estimation of this model disregards sources of heteroskedasticity and correlation between errors. For the former, Case and Shiller (1987) argued in relation to house sales that where there were longer periods between transactions, there was more opportunity for non-market factors to influence the difference between prices. In this context, this could be related back to the likelihood of unobserved improvements or deterioration in unit condition taking place. Therefore, as the time between lettings increases, so may the variance of the errors. Such a relationship is tested empirically for this dataset in section five.

Meanwhile, correlation between errors can arise if there are units that are leased more than twice. For instance, where a unit is let, say, three times over a period, the rental evidence can be used to form two observations of rent change; one between the

\footnotetext{
${ }^{20}$ See especially the critiques in Shiller (1991) and Goetzmann (1992).

${ }^{21}$ This point may be confusing, since geometric means are usually desirable in a time-series setting. Here, it is their computation from cross-sections of evidence that is the problem, with those averages subsequently being chained into a rent time series.
}

(C) 2010. This manuscript version is made available under the CC-BY-NC-ND 4.0 licence http://creativecommons.org/licenses/by-nc-nd/4.0/ 
first letting and the second and one between the second letting and the third. However, any noise associated with the second transaction will influence both observations and cause their error terms in a regression to be related, violating the assumptions of OLS. One solution is simply to construct pairs so that no such conflicts of evidence occur, but this leads to a large number of potential observations being discarded.

Hence, a modified version of the repeat measures regression approach that was first proposed in Shiller (1991) has been utilised here and this addresses several of the issues noted above. The first step involves estimation of the following:

$$
r_{i, 1}=\beta_{2} r_{i, 2}+\beta_{3} r_{i, 3}+\ldots+\beta_{t} r_{i, t}+\ldots+\beta_{T} r_{i, T}+\varepsilon_{i, t}
$$

where $r_{i, 1}$ represents the first time period and takes the value of zero except where the first letting occurs in that period, in which case the annual rent is used instead. The independent variables $\left(\mathrm{r}_{\mathrm{i}, 2} \ldots \mathrm{r}_{\mathrm{i}, \mathrm{T}}\right)$ then represent subsequent periods and are populated by rents where lettings occur and by zeros otherwise, with the rents taking a negative sign in the case of the first transaction and a positive sign in the case of the second deal.

By using rent rather than log rent differences in the dependent variable, this new model avoids the geometric averaging bias of the specification in Bailey, et al. (1963). Using rents throughout also means that a value weighted series is produced. However, since the new model includes rents in the matrix of independent variables, this creates an errors-in-variables problem because rents are noisy signals of the market price for their respective units of space. To tackle this, the model must be estimated using the 
instrumental variables technique rather than OLS. The panel of dummy variables from the initial model forms a logical set of instruments for this purpose. ${ }^{22}$

As yet, the new model does not address the issues of heteroskedasticity and nonindependence of errors. Given knowledge of the nature of these problems, though, it is possible to use a feasible generalized least squares approach, which should lead to more efficient estimates of the rent index in each year. This requires further steps to be taken, namely the construction and application of an appropriate weighting matrix. Shiller (1991) outlines a structure for this matrix and suggests how its parameters might be derived empirically.

Specifically, to construct a weighting matrix, a second regression is performed in which error terms from estimation of the first step are decomposed into time and nontime components:

$$
\left|\varepsilon_{\mathrm{i}, \mathrm{t}}\right|=\alpha+\beta_{\mathrm{j}} \mathrm{X}_{\mathrm{i}, \mathrm{j}}
$$

where $X_{i, j}$ measures the time period between lettings in each case, $\beta_{\mathrm{j}}$ captures the time related element of error and $\alpha$ captures the non-time element. ${ }^{23}$ If the slope coefficient is significant and positive, this indicates that the size of errors and the length of time between transactions are related, in which case, to control for such heteroskedasticity, fitted values from this step can be squared and used for the diagonal elements of the

\footnotetext{
${ }^{22}$ Shiller (1991: 115).

${ }^{23}$ Using absolute values of the errors for the dependent variable is different to the procedures in Shiller (1991). However, when using squared errors, the second step regression for this dataset produced some negative fitted values and this prevented a weighing matrix from being assembled.
}

(C) 2010. This manuscript version is made available under the CC-BY-NC-ND 4.0 licence http://creativecommons.org/licenses/by-nc-nd/4.0/ 
weighting matrix. In effect, those observations that have a long time interval between lettings are down-weighted as a result of this procedure. ${ }^{24}$

To counter the effects of error correlation, the off-diagonal elements of the same matrix must also be populated. It is the non-time component of error that is correlated across those observations where lettings are used more than once. As noted above, the noise associated with the shared transaction will influence both pairs. So the value of the constant, which estimates the non-time component, is divided in two (as each pair comprises two lettings) and squared (since the second step here uses absolute errors). The resulting figure is then used to populate the off-diagonals of the weighting matrix for observations that share rental evidence with other cases.

After the weighting matrix has been assembled, the third step in the process is to estimate the model from the first step (including instruments) using generalized least squares. The value-weighted rent index is then constructed by taking the reciprocal of the beta coefficients measured for each period. This modified model does not address all criticisms of the repeat measures method, though. For instance, in housing studies, the extent to which repeatedly traded houses are representative has been questioned. ${ }^{25}$ This could also be an issue for rented office space, but, with limited descriptive data, this was difficult to analyse properly here.

Meanwhile, the potential for results to reflect unobserved changes to units is still present, whilst, even no alterations occur, buildings inevitably age and this introduces

\footnotetext{
${ }^{24}$ Alternatively, if heteroskedasticity is concentrated in cases with very long intervals between the two constituent lettings, one could remove such observations entirely. As a robustness check on the results below, the first step was estimated with 263 pairs removed where the time gap was more than 20 years. However, the index results were similar to those of the full model that employs reweighting, whilst the second step continued to suggest a time-error relationship.

${ }^{25}$ For example, see Gatzlaff and Haurin (1997).

(C) 2010. This manuscript version is made available under the CC-BY-NC-ND 4.0 licence http://creativecommons.org/licenses/by-nc-nd/4.0/
} 
depreciation into the series. However, the previous section argued that the age profile of the sample assets was typical for the City office market over most of the period being studied. Furthermore, given the data available, it is contended that a repeat measures approach was the most practical method for estimating a series of this nature and is more robust than taking a simple average of rents achieved in each year. The paper now considers the results generated by adopting this approach.

\section{Estimations and results}

To apply the model to the data collected here, lettings first had to be arranged so that consecutive transactions of the same space could be identified. However, not all parcels of space were subject to more than one letting over the period that their source documents covered. Of the 9,141 lettings in the dataset, only 6,962 (76\%) could be made into pairs, although this is still a high proportion of the available evidence. On the other hand, because many units let more than twice over the time frame, the 6,962 transactions generated a total of 5,125 pairs upon which the estimations in this section have been based.

The pairing process remained alert to changes in the size or nature of rooms and pairs involving lettings that occurred within 12 months of each other were avoided in order to maintain consistency with the choice of an annual frequency for construction of the index. Each pair was then formatted into a single observation of rental change. The resulting panel of data was then used to estimate rent indices based on both the modified repeat measures model and the original model of Bailey, et al. (1963). This was so that the extent of the benefits from adopting the modified approach could be assessed. 
Before moving to the indices themselves, it is useful to consider the results from the intermediate steps of the FGLS repeat measures procedure. The first step, itself an index producing model, achieved a good fit on the data with an F-statistic of 129.47, easily significant at the $1 \%$ level. The second step regression then utilised the absolute values of the residuals from this first step, regressing them on to a variable measuring the time gap between the two transactions in each case. ${ }^{26}$ The estimate of the timeerror relationship from this was as follows (standard errors in parentheses):

$$
\left|\varepsilon_{\mathrm{i}, \mathrm{t}}\right|=1.874+0.227 \times \text { Years }
$$

$(0.163)(0.017)$

$$
\text { Observations }=5125, \quad \mathrm{R}^{2}=3.2 \%, \quad \text { F-statistic }=169.3
$$

Although the explanatory power of the error model is low, it can be seen that the size of errors from the first stage regression is positively related to the time interval between lettings, as hypothesised in the previous section. ${ }^{27}$ The coefficient on Years is significant at the $1 \%$ level. The parameters for the weighting matrix were then computed in the manner described above and the third step GLS estimation applied in order to derive a final index series.

The rent index and its 95\% confidence intervals are shown in Figure 2. The index has been rebased so that $1913=1$, whilst logarithms of the index values are charted to

\footnotetext{
${ }^{26}$ Although labelled as Years, this variable is first calculated in terms of the number of days and then rescaled.

${ }^{27}$ It is also the case that the $\mathrm{R}^{2}$ is larger than those found by Case and Shiller (1987: 55) when testing these techniques on house price datasets.

(C) 2010. This manuscript version is made available under the CC-BY-NC-ND 4.0 licence http://creativecommons.org/licenses/by-nc-nd/4.0/
} 
provide a clearer representation of growth rates through time. Meanwhile, summary statistics for the series are presented in Table 3, which splits the period covered by the index in half to reveal both economic and statistical differences between the earlier and later years. The trends here are very similar to those found when using the Bailey, et al. (1963) model, but the confidence intervals are narrower. This is demonstrated in the charts in Appendix A.

\section{INSERT FIGURE 2}

\section{INSERT TABLE 3}

It is clear from Figure 2 that the rent index is measured with more confidence from c.1905 onwards. This is unsurprising given the distribution of lettings indicated in Figure 1. Table 3 reveals that there is strong negative autocorrelation in the series (as measured on the annual changes) during the earlier years. This is also connected to the amount of underlying data, with index estimates influenced by noise in those years where data is sparse. ${ }^{28}$ Therefore, year-to-year changes in the early period should be treated with caution and interpretation in this paper will mainly focus on trends.

A second thing to note is that, whilst strong periods of rental growth are apparent from Figure 2 for the second half of the time frame, the picture in real terms is very different, with Table 3 indicating that real change in City office rents was, on average, slightly negative after 1913. As a result, there has effectively been no real growth in the level of rents over the period the series covers. This, on its own, is an interesting

\footnotetext{
${ }^{28}$ A saw-tooth effect in the presence of sparse data is well documented in studies of the repeat measures technique (see Goetzmann, 1992: 9-10).

(C) 2010. This manuscript version is made available under the CC-BY-NC-ND 4.0 licence http://creativecommons.org/licenses/by-nc-nd/4.0/
} 
finding given the historical and contemporary status of the City as a prime location for office investment. It is also mirrors the results of Wheaton, et al. (2009) in respect of office prices in New York, where they found that, in the long run, real estate has done no more than hold its value against inflation, delivering returns to owners primarily in the form of income.

To provide further comparison with inflation, Figure 3 displays the rent index alongside the national GDP deflator as the selected measure of inflation in this study. The deflator was calculated from expenditure side estimates of UK GDP at factor cost presented in Mitchell (1988). Although more recent work has produced balanced estimates of GDP for certain sub-periods, this series provided a consistent deflator for the whole period spanned by the rent index. ${ }^{29}$ It is this that has been used to compute real values of the rent index, the trends in which are illustrated in Figure 4.

\section{INSERT FIGURE 3}

\section{INSERT FIGURE 4}

Figures 2-4 show distinct phases of growth and decline in City office rents. In the literature on modern office markets, several variables have been identified as drivers of trends in rents over time. ${ }^{30}$ Fundamentally, demand for office space is derived from demand for goods and services in the wider economy and, in particular, by sectors of

\footnotetext{
${ }^{29}$ The website www.measuringworth.com does, however, splice together different series to produce a deflator for the whole period on a market price basis. This shows slightly greater inflation, but using it does not produce materially different results.

${ }^{30}$ See Lizieri (2009), chapter 4, and Clapp (1993) for reviews.

(C) 2010. This manuscript version is made available under the CC-BY-NC-ND 4.0 licence http://creativecommons.org/licenses/by-nc-nd/4.0/
} 
the economy that are significant office space users. For a given location, rents are also likely to reflect the changing advantages of that location for business and the supply response to such changes in the form of new office construction.

In the case of the City, this index should, therefore, reflect historical trends in its economic performance, in the numbers employed in finance and business services, in office construction, and by changes to the competitive position of the City versus that of other locations. In addition, over this particular period, developments in technology and transport, and changes to the way in which offices were used may be important influences. Within the scope of this paper, it is not possible to develop a full analysis of all these aspects, but they are drawn upon to interpret the main trends, which are now discussed.

First, it can be seen from Figure 4 that, after an initial period of no growth, office rents rose in real terms from the 1880s until the turn of the twentieth century. This rise occurred in the context of rapidly growing demand for office space, which was fuelled by several factors. One of these was expansion in the City's financial functions as its significance as a national and international financial centre grew from mid-century onwards. ${ }^{31}$ Another was growth in trade. This did not necessarily relate to trade that passed through London itself, as the City was increasingly important as a location for the coordination of trade that took place elsewhere. ${ }^{32}$ Both these changes were greatly facilitated by developments in communications. ${ }^{33}$

\footnotetext{
${ }^{31}$ Michie (1997: 76-78); Ball and Sunderland (2001), chapter 14.

${ }^{32}$ A phenomenon termed 'office trade' in Michie (1992: 33).

${ }^{33}$ Michie (1992: 38-41); Ball and Sunderland (2001: 347-348, 360).

(C) 2010. This manuscript version is made available under the CC-BY-NC-ND 4.0 licence http://creativecommons.org/licenses/by-nc-nd/4.0/
} 
Demand was manifested through the growth of office employment in this period. Although this growth is well established, it is difficult to quantify exactly. ${ }^{34}$ A general sense may be gathered from figures on the daytime population of the City, which rose from around 200,000 in 1871 to over 330,000 by $1901 .^{35}$ Meanwhile, the residential population fell, reflecting demand for commercial land uses and an increasing ability to commute to the City from further afield as rail and other transport improvements occurred. ${ }^{36}$ The relative value of land in residential use declined and this encouraged the conversion and replacement of domestic premises by office buildings, a pattern already evident in the centre of the City earlier in the century. ${ }^{37}$

However, the increase in the supply of office space resulting from this process is likely to have acted as a break on rents, preventing them from rising too rapidly. This is supported by the experiences of the City Offices Company, which, as a landlord of centrally located office properties, suffered recurring setbacks to its expectations of growth. ${ }^{38}$ Yet limits to the speed and magnitude of supply did exist, such as difficulties in assembling sites, ${ }^{39}$ restrictions in terms of building height, ${ }^{40}$ and limits to the distance over which some activities could disperse owing to their need in this

\footnotetext{
${ }^{34}$ Turvey (1998: 53).

${ }^{35}$ Dunning and Morgan (1971: 34); Michie (1992: 14).

${ }^{36}$ Dunning and Morgan (1971: 33-36); Kynaston (1995: 244-246).

${ }^{37}$ Keene (1997: 265, 268-269).

${ }^{38}$ Scott (1996: 23-26); Turvey (1998: 60-61).

${ }^{39}$ See Keene (1997: 270) or Black (2000: 367) for examples.

${ }^{40}$ These limits were initially economic as much as regulatory, with it being difficult to attract tenants for higher floors, although this was later mitigated by the installation of lifts (Lawrence, 1994: 28; Turvey, 1998: 62).
}

(C) 2010. This manuscript version is made available under the CC-BY-NC-ND 4.0 licence http://creativecommons.org/licenses/by-nc-nd/4.0/ 
period to be near institutions and information networks. ${ }^{41}$ Thus, the limited rise in real rents found here appears realistic.

With these points in mind, the rent index can be compared with that constructed by Turvey (1998) in his study of the City office market in Victorian and Edwardian times. The two series are shown in Figure 5 for the years that they both cover, with each rebased so that $1869=1$. The graph indicates that the indices follow a similar path until the late $1880 \mathrm{~s}$, but, from this date, the Turvey series begins to rise more quickly. In fact, annualised rental growth over the period $1887-1899$ is $3.0 \%$ p.a. for the Turvey index versus $0.8 \%$ p.a. for the index constructed here. ${ }^{42}$

\section{INSERT FIGURE 5}

Without information on the confidence intervals around the Turvey series, it is difficult to judge whether the levels of the indices diverge in a statistically significant way. However, the Turvey series rises above the upper $95 \%$ bound for this index in 1896 and it may be significantly higher by 1904/5, assuming that its own confidence intervals are of a similar size. ${ }^{43}$ Nonetheless, both series are consistent in showing that rental growth stalled in the Edwardian era. This is likely to reflect slowing demand in the context of more uncertain economic and political conditions, and further increases in the supply of office buildings by this point.

\footnotetext{
${ }^{41}$ Ball and Sunderland (2001: 336, 362).

${ }^{42}$ The start point is partially affected by noise, but not to the same extent as, for instance, 1886.

${ }^{43}$ This may not be realistic given the confidence intervals generated when using the Bailey, et al.

(1963) procedure on this dataset - see Appendix A.

(C) 2010. This manuscript version is made available under the CC-BY-NC-ND 4.0 licence http://creativecommons.org/licenses/by-nc-nd/4.0/
} 
Any recovery in office rents was halted by the onset of the First World War. As shown in Figure 3, inflation rose dramatically and rents initially fell, resulting in a large decline in real terms across 1914-18. After the war, activity returned to the City and strong nominal increases in rents can be observed. Yet, even with deflation taking place in the wider economy, it was some time before real rents regained their prewar level. In fact, the real value of the index in 1913 is not matched again until 1927, after which both nominal and real rents decreased, reflecting not only domestic economic difficulties, but also growing restrictions on the City's international role that led to a decline in several areas of trade and financial activity. ${ }^{44}$

Furthermore, although there was not much speculative office development in the interwar period, supply was relatively plentiful because of the amount of construction that occurred before $1914 .{ }^{45}$ However, the fall in rents appears to have slowed in the mid-1930s (and even stopped in nominal terms) before resuming with the approach and commencement of the Second World War. This then proceeded to have a major impact not only on business, but also on the physical landscape. It is estimated that one third of the built area of the City was destroyed by bombing and this included approximately six million square feet of office space, with several buildings in the dataset thus affected. ${ }^{46}$

Another legacy of the Second World War was a shift in the composition of office demand. Physical destruction had forced relocation upon many businesses, whilst the subsequent shortage of space caused rents to rise. These factors led to the permanent loss of some activities and an increased focus on finance, especially the non-routine

\footnotetext{
${ }^{44}$ Michie (1997: 80-81); Baum, et al. (1998: 8).

${ }^{45}$ Marriott (1967: 18-20).

${ }^{46}$ Holden and Holford (1951: 184, 274); Dunning and Morgan (1971: 32).

(C) 2010. This manuscript version is made available under the CC-BY-NC-ND 4.0 licence http://creativecommons.org/licenses/by-nc-nd/4.0/
} 
elements. ${ }^{47}$ Rapid growth in rents was supported by postwar regulatory constraints on replacement of the office stock. For instance, building licences for office development were only granted in certain conditions, such as construction for a priority end-user, in order to control scarce resources. ${ }^{48}$

Meanwhile, restrictions on obtaining finance and a very high taxation of property development acted as further deterrents to building new office accommodation. ${ }^{49}$ In this context, the strong growth in both the nominal and real rent series is reasonable. Yet growth is apparent throughout the 1950s, even as restrictions were being relaxed or lifted and as the volume of office building increased. ${ }^{50}$ Thus, it appears that pent-up demand together with further expansion of the service sector was able to soak up the flow of new space built during this decade. ${ }^{51}$ However, by the early 1960 s, the extent of new supply was causing the City office market to run into difficulties. ${ }^{52}$

Table 4 presents annualised rental growth rates for the whole period and for subperiods based on those used by Matthews, et al. (1982) in their study of the British economy. The rates are simply calculated from the start and end index values for each time frame and should not necessarily be taken as typical for the intervening years. ${ }^{53}$

\footnotetext{
${ }^{47}$ Michie (1992: 18-20); Baum, et al. (1998: 12-13).

${ }^{48}$ For example, companies that were manufacturing for export or government departments. Rose (1985: 
This should be clear from the standard errors around the average growth rates, which are also provided, and from inspection of Figures 3-4. Thus, for example, real growth of $-0.6 \%$ p.a. represents the net outcome of the period 1913-1924 for office rents, but masks some considerable underlying movements.

\section{INSERT TABLE 4}

Nonetheless, the rates are interesting in the sense that they confirm how rental growth has differed markedly through the different economic environments discussed above. They quantify the extent of gradual growth through a stable inflationary era (1867-1913), of nominal and real declines in a deflationary era (1924-37) and of rapid rental growth in a highly inflationary era, assisted by regulatory factors (1951-59). Meanwhile, the trans-war periods stand out as times where office rents lagged strong inflationary trends.

\section{Spatial differences}

So far, the analysis and discussion has treated the City office market as if it were a homogeneous entity. However, there are reasons why this might not be appropriate. First, over the period covered by the rent index, the office areas of the City expanded, particularly during the nineteenth century and, again, from the mid 1950s. As a result, locations that were previously peripheral may have become more established and thus seen growth in rents not experienced by traditional core areas.

Second, studies have shown that the City contained a diverse mix of economic activities prior to the Second World War. ${ }^{54}$ These activities manifested themselves in

\footnotetext{
${ }^{54}$ Michie (1992: 16-18); Ball and Sunderland (2001: 359).

(C) 2010. This manuscript version is made available under the CC-BY-NC-ND 4.0 licence http://creativecommons.org/licenses/by-nc-nd/4.0/
} 
different districts. Holden and Holford (1951) represent this by illustrating the City at 1938 as a series of economic zones. ${ }^{55}$ In addition, using postwar employment data, Dunning and Morgan (1971) demonstrated the clustering of specific office based activities in particular areas. This suggests that locations in different parts of the City may have been subject to different demand side influences.

These points raise questions as to whether a single series fully represents rent trends in the City office market or whether distinct trends can be found for different districts within its boundaries. On the other hand, whilst the level of rents has varied according to location, reflecting factors such as proximity to the Bank of England, it may be that trends in different areas have been consistent. If this were so, then this would suggest that relative differences in rent levels between locations have persisted over time.

The dataset collected for this study allows some investigation of these issues. As noted in section 3, the properties in the sample are spread throughout the City. Taking advantage of this, a classification of the buildings according to the economic activity of their location was attempted. This used the zones outlined in Holden and Holford (1951), although during this process, an additional activity labelled 'Commercial \& financial' was created for a group of offices that lay within the commercial zone to the northeast of the Bank of England, but whose occupancy had a consistently strong financial element.

The classification of the sample properties was then used to identify three broad areas for further comparison. These were defined as follows. All offices to the west of the Bank of England (21 properties) were placed into a western group, whilst those to

\footnotetext{
${ }^{55}$ See especially map 2 in Holden and Holford (1951), facing p32. See also Cowan, et al. (1969: 159161).
}

(C) 2010. This manuscript version is made available under the CC-BY-NC-ND 4.0 licence http://creativecommons.org/licenses/by-nc-nd/4.0/ 
the east of a line formed by Bishopsgate and Gracechurch Street (11 properties) comprised an eastern group. The remaining 19 office buildings, which were located between the Bank and this line, then made up the constituents of a 'core' district. The different character of each area is shown in Table 5, which presents the distribution of paired observations by both district and activity group.

\section{INSERT TABLE 5}

This classification has several weaknesses. First, the activity zones are observed only at a point in time and their applicability to an analysis of longer periods may be questioned. Second, Holden and Holford (1951) note that there is no sharp transition in activities from one zone to another, making their boundaries somewhat arbitrary. Third, the occupancy of the properties, whilst partly reflecting the areas in which they were situated, was also fairly mixed. For instance, offices in the east that were located in the Shipping zone had general insurers and other businesses as tenants, as well as occupiers more directly linked with the shipping and handling of goods.

For these reasons, an investigation based on these three areas provides an initial rather than definitive indication of the effect of location. However, one advantage of these areas is that they split the observations in this dataset reasonably evenly. This is demonstrated in Table 5, which reveals that $38 \%$ of the 5,125 pairs are from buildings in the core district, $30 \%$ from those buildings in the east and $31 \%$ from those in the west. Unfortunately, though, as for the main index, the distribution over time is more 
problematic, with all evidence before 1905 relating just to the core district. ${ }^{56}$ In fact, indices for all three areas can only be presented over 1909-1959. ${ }^{57}$

The results of this exercise are summarised by Figure 6, which, for more clarity, charts the five year moving average of the real rent index for each district. Confidence intervals for each series have also been computed, but are again not shown for reasons of clarity.

\section{INSERT FIGURE 6}

From the results, it can be seen that between 1909 and 1939, rental trends in all three areas were similar, although it is interesting to see the sharper fall in real rents in the financially oriented core district across 1929-33. Throughout this time, confidence intervals indicate that the three indices are not statistically distinct from one another. This similarity is perhaps surprising, but the previous section indicated that changes to the office stock in these years were muted compared with those during the nineteenth century. This reduces at least one potential driver of change between areas.

After 1945, though, a visible gap emerges between the series for the core district and those for the other two areas, with rents in the core appearing to rise more slowly. Such a difference would be consistent with two observations. First, there was proportionally greater destruction in both the east and west districts during the Second

\footnotetext{
${ }^{56}$ This is not simply due to the longer pedigree of this district as an office area, but is also a reflection of the start dates of various source documents.

${ }^{57}$ Note, though, that each series was estimated using all the available observations.

(C) 2010. This manuscript version is made available under the CC-BY-NC-ND 4.0 licence http://creativecommons.org/licenses/by-nc-nd/4.0/
} 
World War. ${ }^{58}$ Hence, faster growth in these areas may reflect greater scarcity whilst rebuilding was restricted. Second, Dunning and Morgan (1971: 186) state that, up to the mid 1960s, rents between the Bank of England area and other locations narrowed, as what was considered to be the core of the City expanded outwards.

Yet, whilst this finding is appealing, it must be acknowledged that the divergence does not lead to a statistically significant difference in index levels before the end of the period. Therefore, the main result arising from this analysis is that of similarity in rent trends between different areas of the City for most of the period over which this could be examined. This is notwithstanding variations in the level of rent paid across different locations.

\section{Conclusion}

The assembly and analysis of rental evidence in this study has enabled a long run index of office rents in the City of London to be constructed. The research improves on an earlier study by Turvey (1998) in terms of method, source documents used and length of time that is covered. Over the 92 year period that the index spans, there has been almost no real growth in the level of office rents. However, sub-periods show distinct trends, with rising real rents to 1914 , falling rents from the end of the 1920 s and through the 1930s, and rising rents in nominal and real terms after the Second World War. These trends appear realistic in the light of what is known about demand conditions and office supply across the period, and mirror the changing fortunes of the City as a centre for economic activity.

\footnotetext{
${ }^{58}$ Figures for the extent of destruction in different areas are given in Holden and Holford (1951: 274), with comparison drawn between areas 10 (core), 11 (east) and 7 and 9 (west).

(C) 2010. This manuscript version is made available under the CC-BY-NC-ND 4.0 licence http://creativecommons.org/licenses/by-nc-nd/4.0/
} 
For economic analysis of the property market and urban change in this location, the study provides a price dimension, which compliments previous research on the City's physical development. In addition, the index gives insights into the long term performance of office property as an investment and the changing cost of occupying office space to City businesses. The study also supplies some evidence on the leasing practices that influence both returns and costs through a separate examination of the dataset. However, for fuller analysis of these areas, further evidence must be gathered on factors such as building occupancy, asset expenditure and the incidence and extent of property taxes over the period concerned. This suggests useful future extensions of the work presented here.

It is acknowledged that the index here does have some limitations with respect to tracking rents. One of these is the small number of observations during the nineteenth century, which limits the extent to which short interval changes can be reliably linked with particular events, such as the periodic building booms or financial crises that occurred in these years. It is also a shame that the dataset does not permit extension of the series into the 1960s and beyond, during which decentralisation of office activities from London gathered pace and further government intervention in the office market occurred.

As it is, whilst other rental data for the 1960s exists, the quality and coverage of this data varies. ${ }^{59}$ This hampers extension of the picture towards the present day, as it is not until later that more authoritative indices emerge. However, there are interesting comparisons with data available for the last thirty years, which shows that City office rents have not grown in real terms and that the volatility of the rental market may

\footnotetext{
${ }^{59}$ For instance, some data on postwar London office rents is presented in Rose (1985: 161), in Dunning and Morgan (1971: 187) and by Manners and Morris (1986: 45-46).
}

(C) 2010. This manuscript version is made available under the CC-BY-NC-ND 4.0 licence http://creativecommons.org/licenses/by-nc-nd/4.0/ 
have increased. ${ }^{60}$ This suggests another interesting extension in terms of analysing the similarities and differences between historical and contemporary market experiences.

Other limitations noted earlier in this paper relate to the depth of information on many lettings and the nature of the index construction technique employed. However, it is contended that the series presented here provides useful historical data on the City of London office market and it is hoped that the findings can be drawn upon in other research. The patterns in rents that the index reveals have had an important influence in shaping the physical landscape found in the City today.

\section{Appendix A: Comparison of repeat measures methods}

This appendix compares two versions of the City office rent index: that based on the preferred model and which was used in the analysis and commentary above, and a second series that has been estimated using the original repeat measures procedure of Bailey, et al. (1963). The motivation for this comparison is to see the extent to which adopting the preferred method has led to different findings.

Figure A1 shows the path through time of the two office rent indices, which are labelled after the authors of the models used. As noted in section five, the trends in the two are very similar. In fact, their annualised compound growth rates over the whole period are almost identical, being $1.75 \%$ p.a. for the BMN series and $1.78 \%$ p.a. for that based on the Shiller technique. This may appear to contrast with comments in section four about bias arising from the formulation of the BMN model. However, the Shiller model not only avoids geometric averaging bias, but also takes values and time

\footnotetext{
${ }^{60}$ The data examined was for the period 1980-2008 and produced by Investment Property Databank, the main provider of indices for the UK institutional property market. See www.ipd.com.

(C) 2010. This manuscript version is made available under the CC-BY-NC-ND 4.0 licence http://creativecommons.org/licenses/by-nc-nd/4.0/
} 
intervals into account when weighting observations and this will have an impact on its results.

\section{INSERT FIGURE A1}

Figure A2 then illustrates the size of the $95 \%$ confidence intervals for the indices produced by each technique, scaled in proportion to the index value for each period. It should be noted that the confidence intervals are symmetric around the estimators in the underlying regressions, but do not remain so once transformation into index values is made. ${ }^{61}$ The chart shows that the difference between models in terms of confidence about index values is large. Confidence intervals from the Shiller model are narrower for nearly all of the period covered and appear more sensitive to data availability in different years, whereas those from the BMN model are uniformly wide, even in years where many transactions occurred.

\section{INSERT FIGURE A2}

\footnotetext{
${ }^{61}$ The transformations are an exponential transform of coefficients in the case of the BMN model and a reciprocal transform of coefficients (as noted earlier) in the Shiller case.

(C) 2010. This manuscript version is made available under the CC-BY-NC-ND 4.0 licence http://creativecommons.org/licenses/by-nc-nd/4.0/
} 


\section{References}

Bailey, M.J., Muth, R.F., Nourse, H.O., 1963. A Regression Method for Real Estate Price Index Construction. Journal of the American Statistical Association 58, 933942.

Ball, M., 1996. London and Property Markets: A Long-term View. Urban Studies 33, 859-877.

Ball, M., Sunderland, D., 2001. An Economic History of London, 1800-1914. Routledge, Oxford.

Baum, A., Lizieri, C., Scott, P., 1998. Who owns the City? An analysis of office ownership in the City of London. University of Reading / Development Securities Plc.

Black, I. S., 2000. Spaces of capital: bank office building in the City of London, 18301870. Journal of Historical Geography 26, 351-375.

Broackes, N., 1979. A Growing Concern. Weidenfeld and Nicolson, London.

Burnand, I.B., 1957. The Gresham House Estate Company Limited, 1857-1957. Privately published, London.

Case, K. E., Shiller, R. J., 1987. Prices of Single-Family Homes since 1970: New Indexes for Four Cities. New England Economic Review Sept/Oct, 45-56.

Clapp, J.M., 1993. Dynamics of Office Markets: Empirical Findings and Research Issues. AREUEA Monograph Series, No. 1, The Urban Institute Press, Washington D.C.

Cowan, P., Fine, D., Ireland, J., Jordan, C., Mercer, D., Sears, A., 1969. The Office: A facet of Urban Growth. Heinemann Educational Books Ltd, London.

Crosby, N., 1988. Shop Rental Value Change in Nottingham. Land Development Studies 5, 185-205.

(C) 2010. This manuscript version is made available under the CC-BY-NC-ND 4.0 licence http://creativecommons.org/licenses/by-nc-nd/4.0/ 
Dunning, J.H., Morgan, E.V., (Eds), 1971. An Economic Study of the City of London. George Allen \& Unwin Ltd, London.

Eichholtz, P.M.A., 1997. A Long Run House Price Index: The Herengracht Index, 1628-1973. Real Estate Economics 25, 175-192.

Feinstein, C.H., 1988. Annex A: Indices of Rent. In: Feinstein, C.H., Pollard, S. (Eds.), Studies in Capital Formation in the United Kingdom 1750-1920. Clarendon Press, Oxford, pp. 405-410.

Gatzlaff, D.H., Haurin, D.R., 1997. Sample Selection Bias and Repeat-Sales Index Estimates. Journal of Real Estate Finance and Economics 14, 33-50.

Goetzmann, W.N., 1992. The Accuracy of Real Estate Indices: Repeat Sale Estimators. Journal of Real Estate Finance and Economics 5, 5-53.

Holden, C.H., Holford, W.G., 1951. The City of London: A Record of Destruction and Survival. Architectural Press, London.

Jefferson Smith, P., 1997. Office Buildings in the City: Royal Exchange Buildings (1841-45). In: Saunders, A., (Ed). The Royal Exchange. The London Topographical Society Publication No. 152, London, pp. 366-385.

Kaiser, R. W., 1997. The Long Cycle in Real Estate. Journal of Real Estate Research $14,233-257$.

Keene, D., 1997. The Setting of the Royal Exchange: Continuity and Change in the Financial District of the City of London, 1300-1871. In: Saunders, A., (Ed). The Royal Exchange. The London Topographical Society Publication No. 152, London, pp. 253-271.

Klovland, J.T., 2009. New evidence on the fluctuations in ocean freight rates in the 1850s. Explorations in Economic History 46, 266-284. 
Kynaston, D., 1995. The City of London - Volume 1: A World of Its Own, 18151890. Pimlico edition, London.

Kynaston, D., 2001. The City of London - Volume 4: A Club No More, 1945-2000. Pimlico edition, London.

L'Anson, E., 1864. Some notice of office buildings in the City of London. Transactions of the Royal Institute of British Architects, 25-36.

Lawrence, J., 1994. From Counting-House to Office: The Transformation of London’s Central Financial District, 1693-1871. Unpublished paper.

Lizieri, C., 2009. Towers of Capital: Office Markets \& International Financial Services. Wiley-Blackwell, Oxford.

Manners, G., Morris, D., 1986. Office Policy in Britain: A Review. Geo Books, Norwich.

Marriott, O., 1967. The Property Boom. Hamish Hamilton, London.

Matthews, R.C.O., Feinstein, C.H., Odling-Smee, J.C., 1982. British Economic Growth, 1856-1973. Stanford University Press, Stanford.

Michie, R.C., 1992. The City of London: Continuity and Change, 1850-1990. Macmillan, Basingstoke.

Michie, R.C., 1997. London and the Process of Economic Growth since 1750. The London Journal 22, 63-90.

Mitchell, B.R., 1988. British Historical Statistics. Cambridge University Press, Cambridge.

Rose, J., 1985. The Dynamics of Urban Property Development. E \& FN Spon, London.

Scott, P., 1996. The Property Masters: A history of the British commercial property sector. E \& FN Spon, London.

(C) 2010. This manuscript version is made available under the CC-BY-NC-ND 4.0 licence http://creativecommons.org/licenses/by-nc-nd/4.0/ 
Scott, P., 2000. The evolution of Britain's urban built environment. In: Daunton, M. (Ed.), The Cambridge Urban History of Britain - Volume III: 1840-1950. Cambridge University Press, Cambridge, pp. 495-523.

Shiller, R.J., 1991. Arithmetic Repeat Sales Price Estimators. Journal of Housing Economics 1, 110-126.

Shiller, R. J., 1993. Macro Markets: Creating Institutions for Managing Society's Largest Economic Risks. Clarendon Press, Oxford.

Summerson, J., 1990. The Victorian Rebuilding of the City of London, 1840-1870. In: Summerson, J., The Unromantic Castle and Other Essays. Thames \& Hudson, London, pp. 193-216.

Turvey, R., 1998. Office Rents in the City of London, 1867-1910. The London Journal 23, 53-67.

Wheaton, W.C., Baranski, M.S., Templeton, C.A., 2009. 100 Years of Commercial Real Estate Prices in Manhattan. Real Estate Economics 37, 69-83. 
Table 1: Data sources and number of transactions

\begin{tabular}{llrr}
\hline Companies studied & Documents & No. of & \multicolumn{2}{c}{ No. of } \\
& & assets & lettings \\
\hline City \& West End Properties & Ms 14,424-Ms 14,425 & 24 & 4,894 \\
Consolidated London Properties & Ms 14,459 & 12 & 1,799 \\
Gresham House Estate Company & Ms 19,599-Ms 19,602 & 6 & 1,444 \\
City Offices Company & Ms 24,190, Ms 24,192 & 8 & 962 \\
Broad Street Estates & Ms 19,610 & 1 & 42 \\
Totals & & 51 & 9,141 \\
\hline
\end{tabular}

Table 2: Average length of office leases (where recorded), 1880-1979

\begin{tabular}{l|ccc}
\hline & $\begin{array}{c}\text { Sample of } \\
\text { lettings }\end{array}$ & \multicolumn{2}{c}{ Mean lease length (years) } \\
& Not weighted & Rent weighted \\
\hline $1880-1889$ & 99 & 6 & 11 \\
$1890-1899$ & 226 & 5 & 13 \\
$1900-1909$ & 326 & 5 & 13 \\
$1910-1919$ & 301 & 6 & 13 \\
$1920-1929$ & 369 & 7 & 12 \\
$1930-1939$ & 317 & 5 & 10 \\
$1940-1949$ & 426 & 5 & 12 \\
$1950-1959$ & 311 & 6 & 10 \\
$1960-1979$ & 38 & 13 & 19 \\
Total & 2,413 & & \\
\hline
\end{tabular}

(C) 2010. This manuscript version is made available under the CC-BY-NC-ND 4.0 licence http://creativecommons.org/licenses/by-nc-nd/4.0/ 
Table 3: Summary statistics for the office rent series - whole period and two subperiods

\begin{tabular}{|c|c|c|c|c|c|c|}
\hline & \multicolumn{3}{|c|}{ Nominal rental growth } & \multicolumn{3}{|c|}{ Real rental growth } \\
\hline & $\begin{array}{l}1867- \\
1913\end{array}$ & $\begin{array}{l}1913- \\
1959\end{array}$ & All years & $\begin{array}{l}1867- \\
1913\end{array}$ & $\begin{array}{l}1913- \\
1959\end{array}$ & All years \\
\hline $\begin{array}{l}\text { Geometric mean } \\
\text { (standard error) }\end{array}$ & $\begin{array}{l}0.6 \% \\
(0.9 \%)\end{array}$ & $\begin{array}{l}3.0 \% \\
(1.1 \%)\end{array}$ & $\begin{array}{c}1.8 \% \\
(0.7 \%)\end{array}$ & $\begin{array}{c}0.6 \% \\
(0.9 \%)\end{array}$ & $\begin{array}{l}-0.4 \% \\
(1.2 \%)\end{array}$ & $\begin{array}{c}0.1 \% \\
(0.8 \%)\end{array}$ \\
\hline $\begin{array}{l}\text { Arithmetic mean } \\
\text { (standard error) }\end{array}$ & $\begin{array}{l}0.8 \% \\
(0.9 \%)\end{array}$ & $\begin{array}{c}3.3 \% \\
(1.2 \%)\end{array}$ & $\begin{array}{l}2.0 \% \\
(0.8 \%)\end{array}$ & $\begin{array}{l}0.8 \% \\
(1.0 \%)\end{array}$ & $\begin{array}{l}-0.1 \% \\
(1.2 \%)\end{array}$ & $\begin{array}{c}0.4 \% \\
(0.8 \%)\end{array}$ \\
\hline Standard deviation & $6.4 \%$ & $7.9 \%$ & $7.3 \%$ & $6.5 \%$ & $8.0 \%$ & $7.2 \%$ \\
\hline First order autocorrelation & -0.45 & 0.27 & 0.02 & -0.42 & 0.31 & 0.02 \\
\hline No. of years & 46 & 46 & 92 & 46 & 46 & 92 \\
\hline
\end{tabular}

Table 4: Annualised rental growth over selected sub-periods

\begin{tabular}{l|cccc}
\hline \multirow{2}{*}{} & \multicolumn{2}{|c}{ Nominal growth } & \multicolumn{2}{c}{ Real growth } \\
& \% p.a. & (St. err) & $\%$ p.a. & (St. err) \\
\hline $1867-1913$ & 0.6 & $(0.9)$ & 0.6 & $(0.9)$ \\
$1913-1924$ & 5.1 & $(3.2)$ & -0.6 & $(4.2)$ \\
$1924-1937$ & -1.9 & $(1.3)$ & -1.2 & $(1.4)$ \\
$1937-1951$ & 4.6 & $(1.9)$ & -0.6 & $(2.0)$ \\
$1951-1959$ & 5.6 & $(1.2)$ & 1.3 & $(1.5)$ \\
Whole period & 1.8 & $(0.7)$ & 0.1 & $(0.8)$ \\
\hline
\end{tabular}

(C) 2010. This manuscript version is made available under the CC-BY-NC-ND 4.0 licence http://creativecommons.org/licenses/by-nc-nd/4.0/ 
Table 5: Count of observations by district and activity of building location

\begin{tabular}{l|ccc}
\hline & Core & East & West \\
\hline Banking & 251 & & \\
Commercial & 11 & 1 & 1,145 \\
Commercial \& financial & 1,690 & & \\
Press \& printing & & & 65 \\
Shipping & & 1,538 & \\
Textiles \& wool & & & 399 \\
Other categories & & 23 & 2 \\
Total & 1,952 & 1,562 & 1,611 \\
\% of all pairs & $38 \%$ & $30 \%$ & $31 \%$ \\
\hline
\end{tabular}

(C) 2010. This manuscript version is made available under the CC-BY-NC-ND 4.0 licence http://creativecommons.org/licenses/by-nc-nd/4.0/ 
Figure 1: Distribution of lettings sample over time

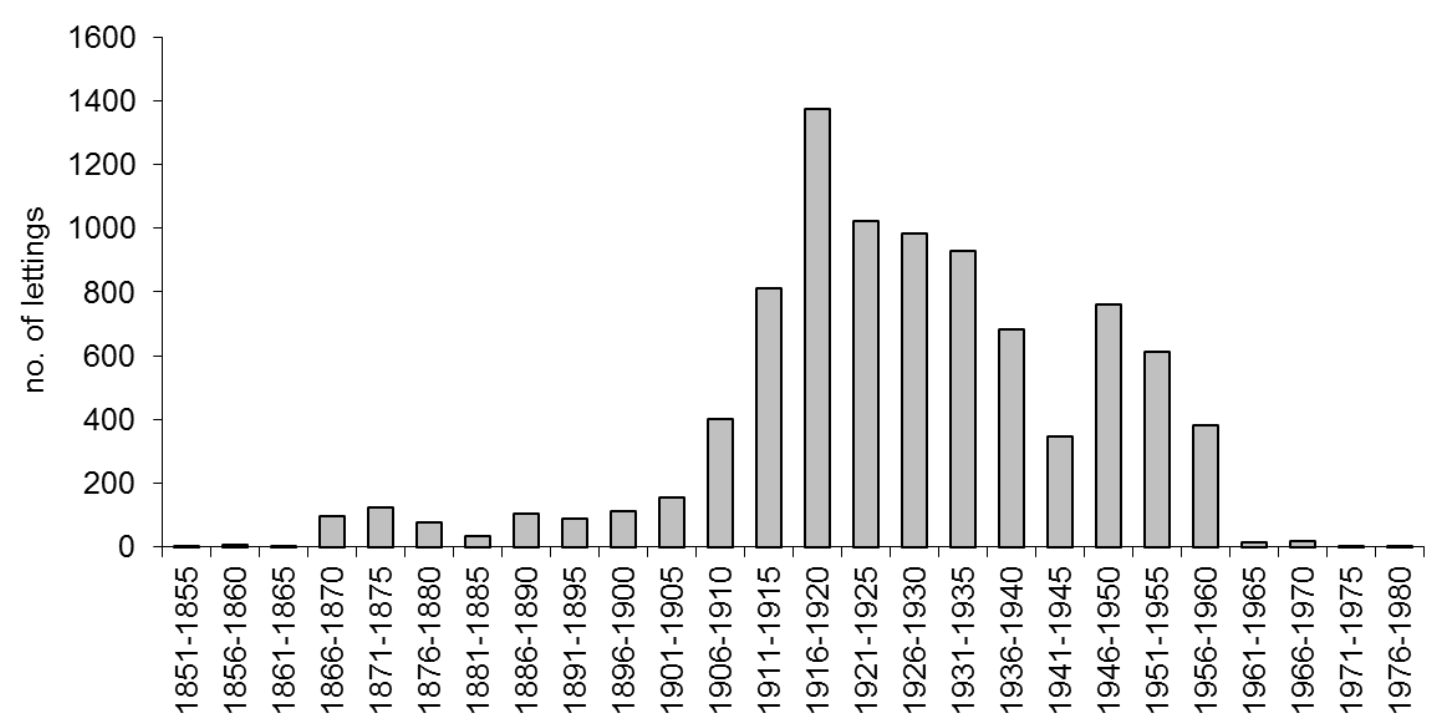

Figure 2: Rent index and 95\% confidence intervals

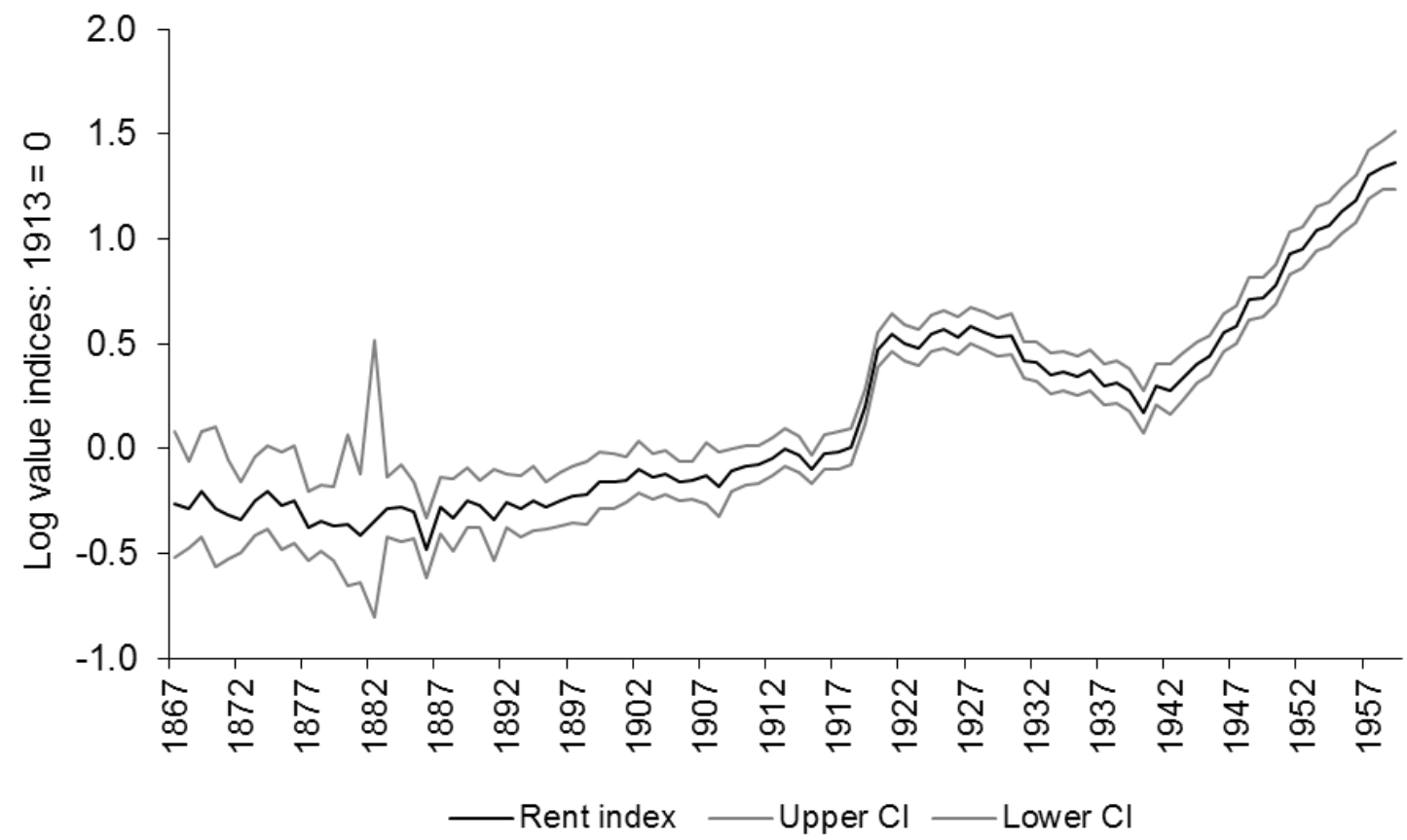

(C) 2010. This manuscript version is made available under the CC-BY-NC-ND 4.0 licence http://creativecommons.org/licenses/by-nc-nd/4.0/ 
Figure 3: Rent index and GDP deflator, 1867-1959

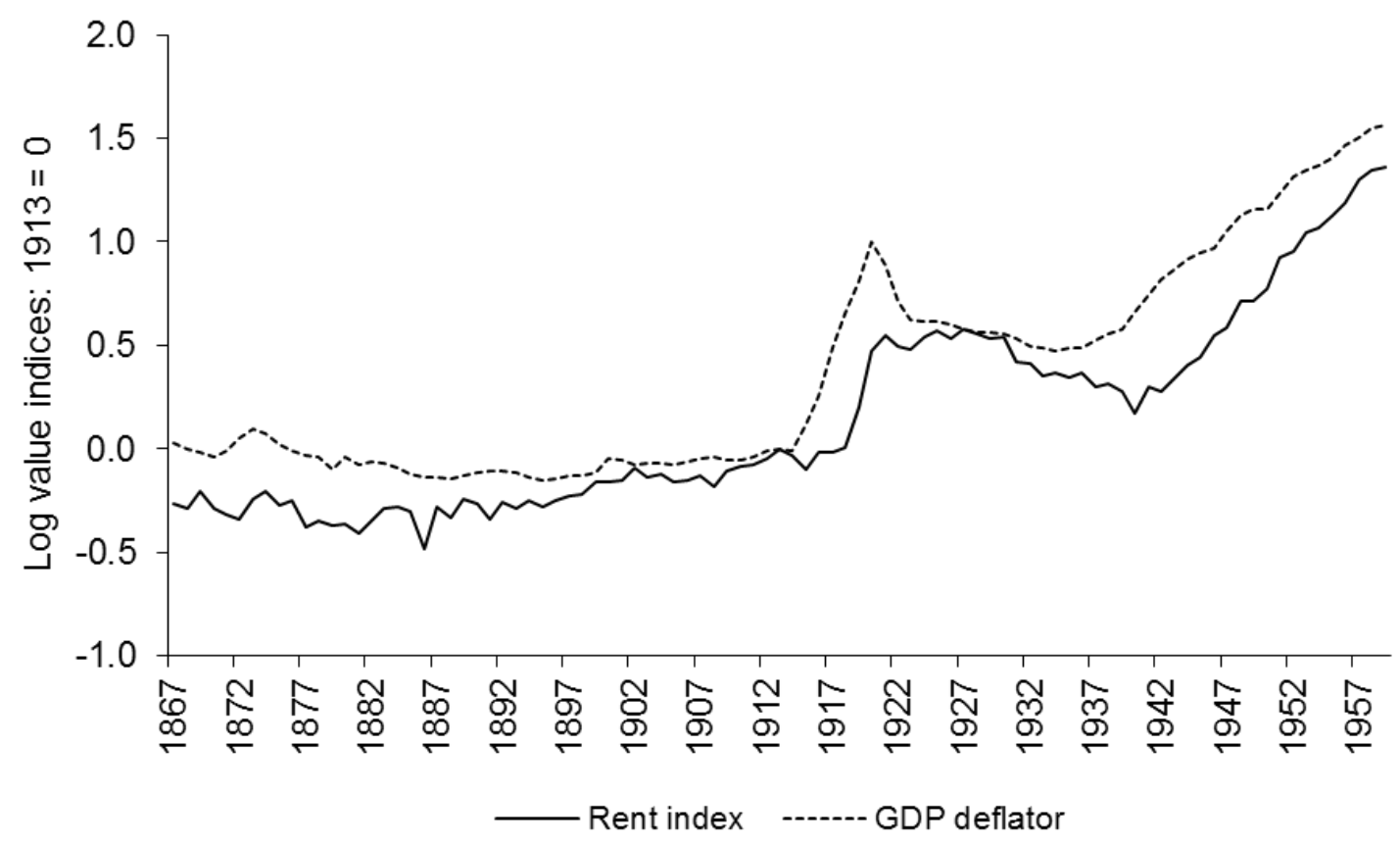

Figure 4: Real values of the rent index, 1867-1959

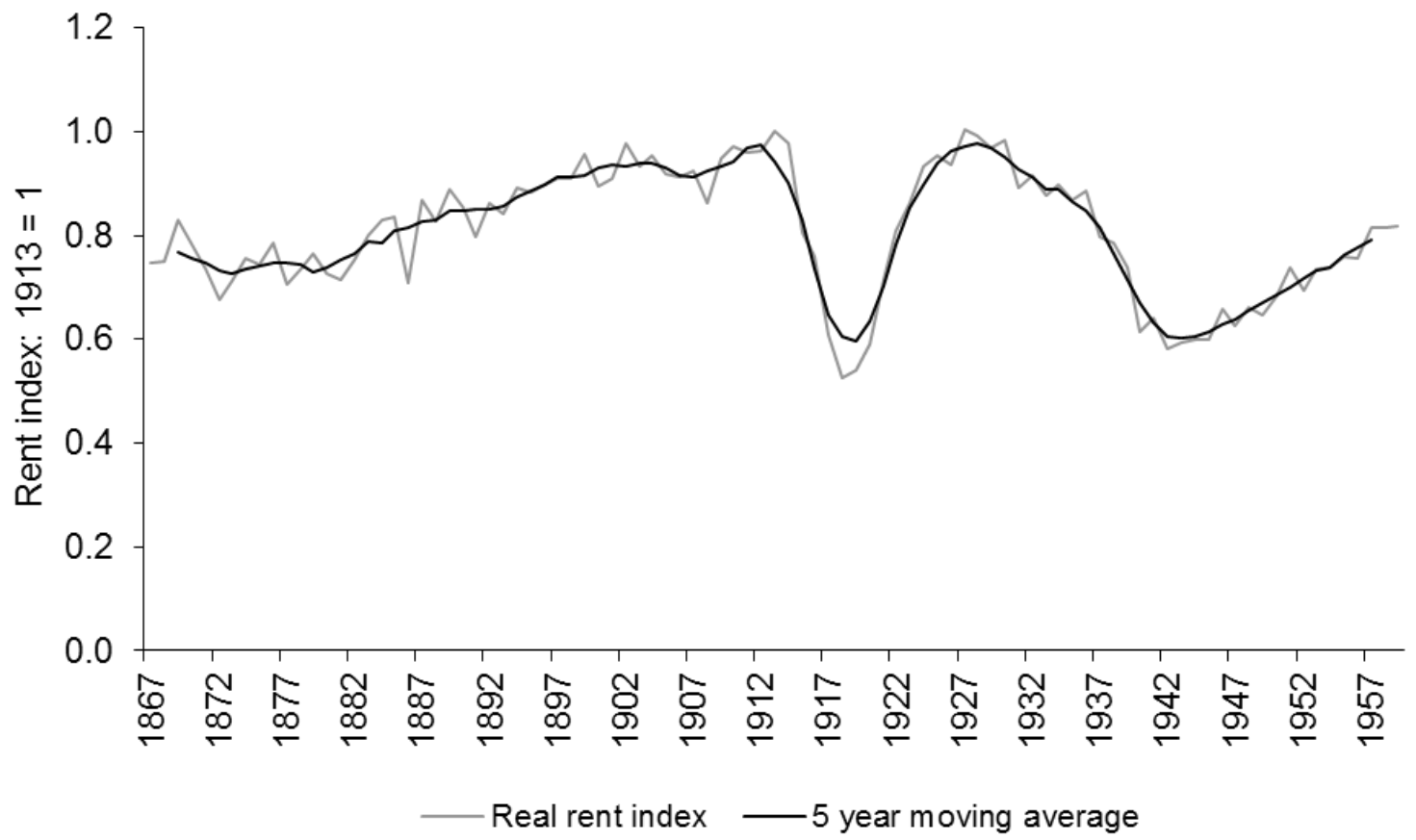

(C) 2010. This manuscript version is made available under the CC-BY-NC-ND 4.0 licence http://creativecommons.org/licenses/by-nc-nd/4.0/ 
Figure 5: Comparison with rent index in Turvey (1998)

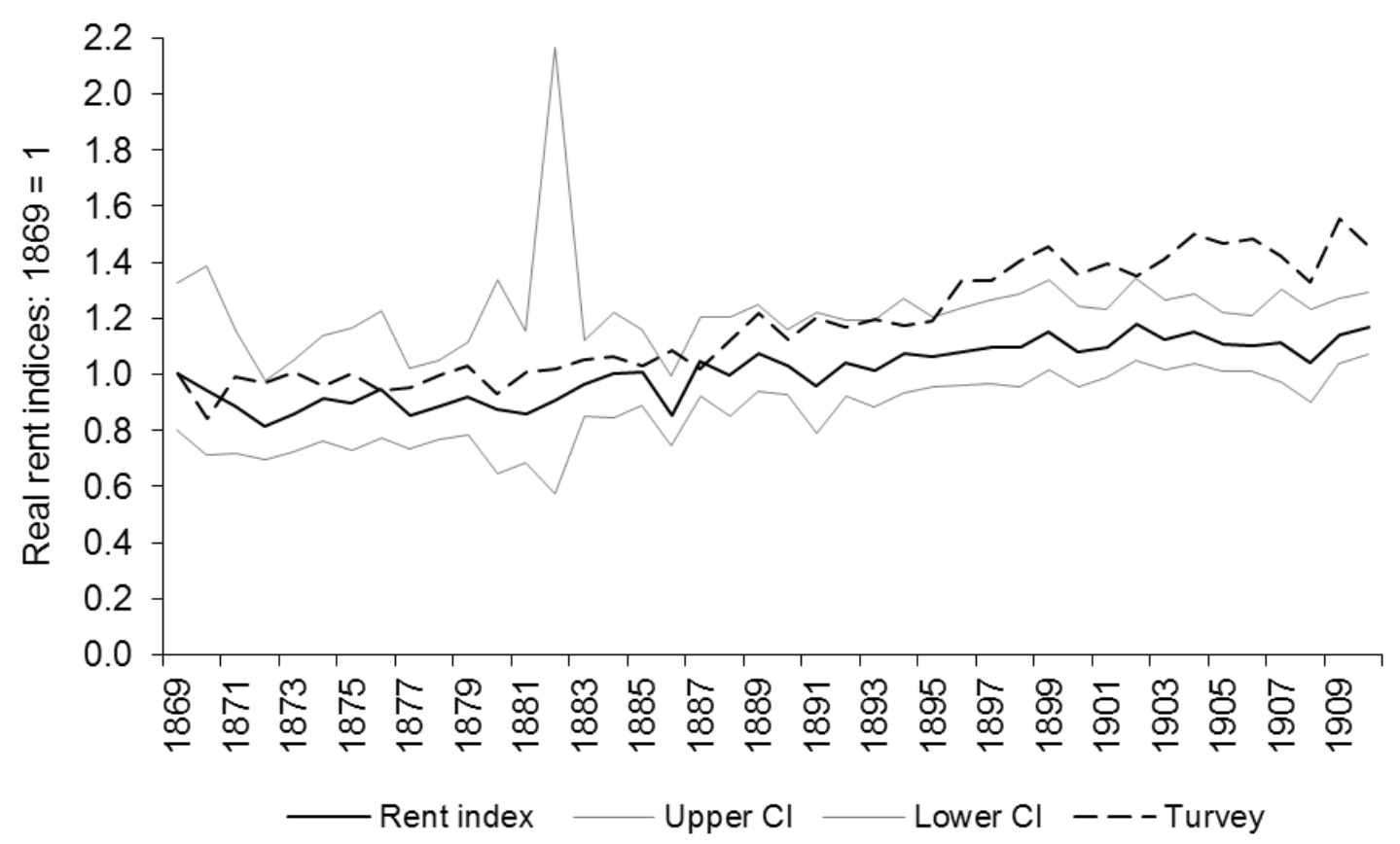

Figure 6: Rental trends by area within the City, 1909-1959

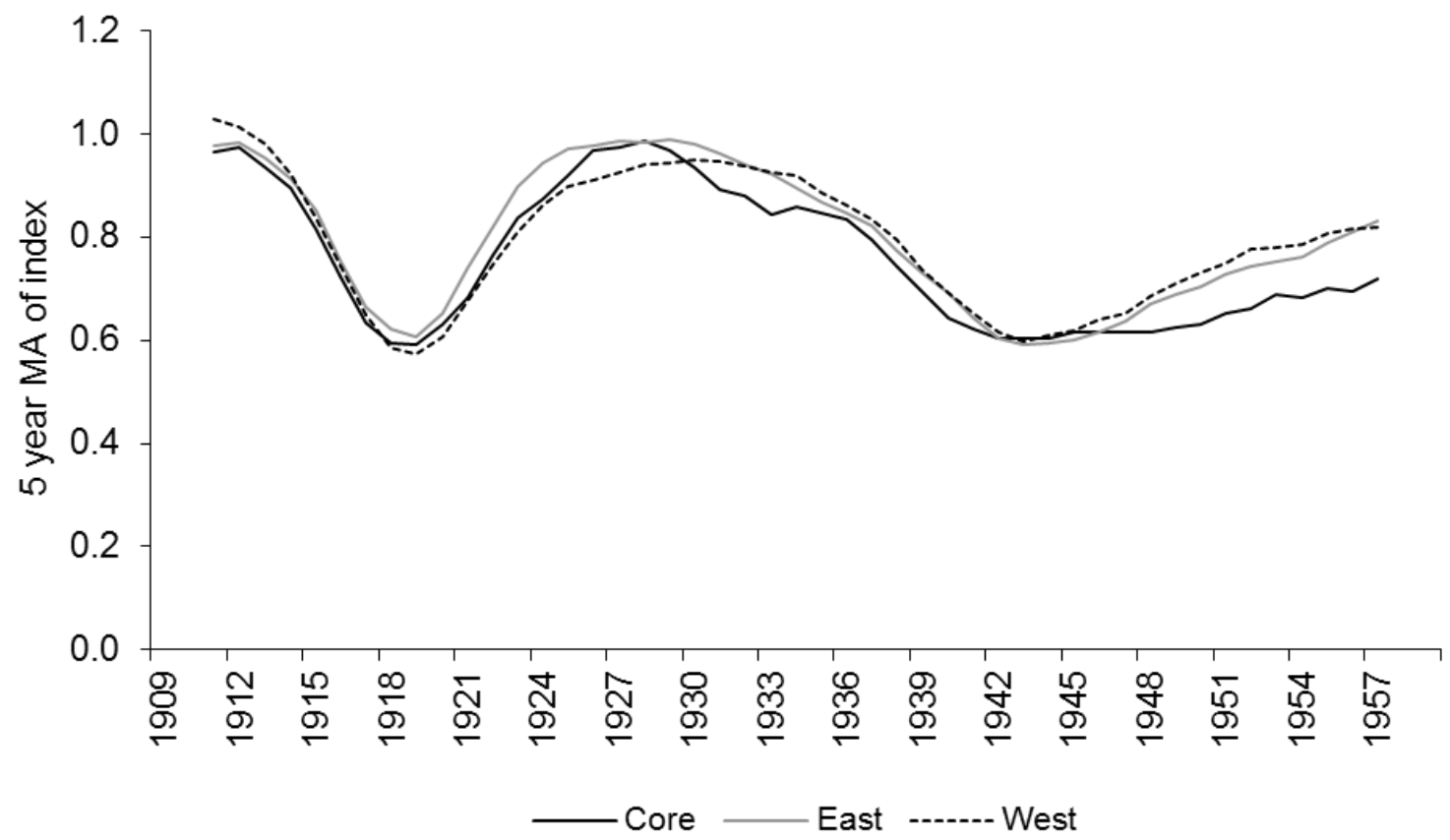

(C) 2010. This manuscript version is made available under the CC-BY-NC-ND 4.0 licence http://creativecommons.org/licenses/by-nc-nd/4.0/ 
Figure A1: Rent indices produced by two repeat measures methods

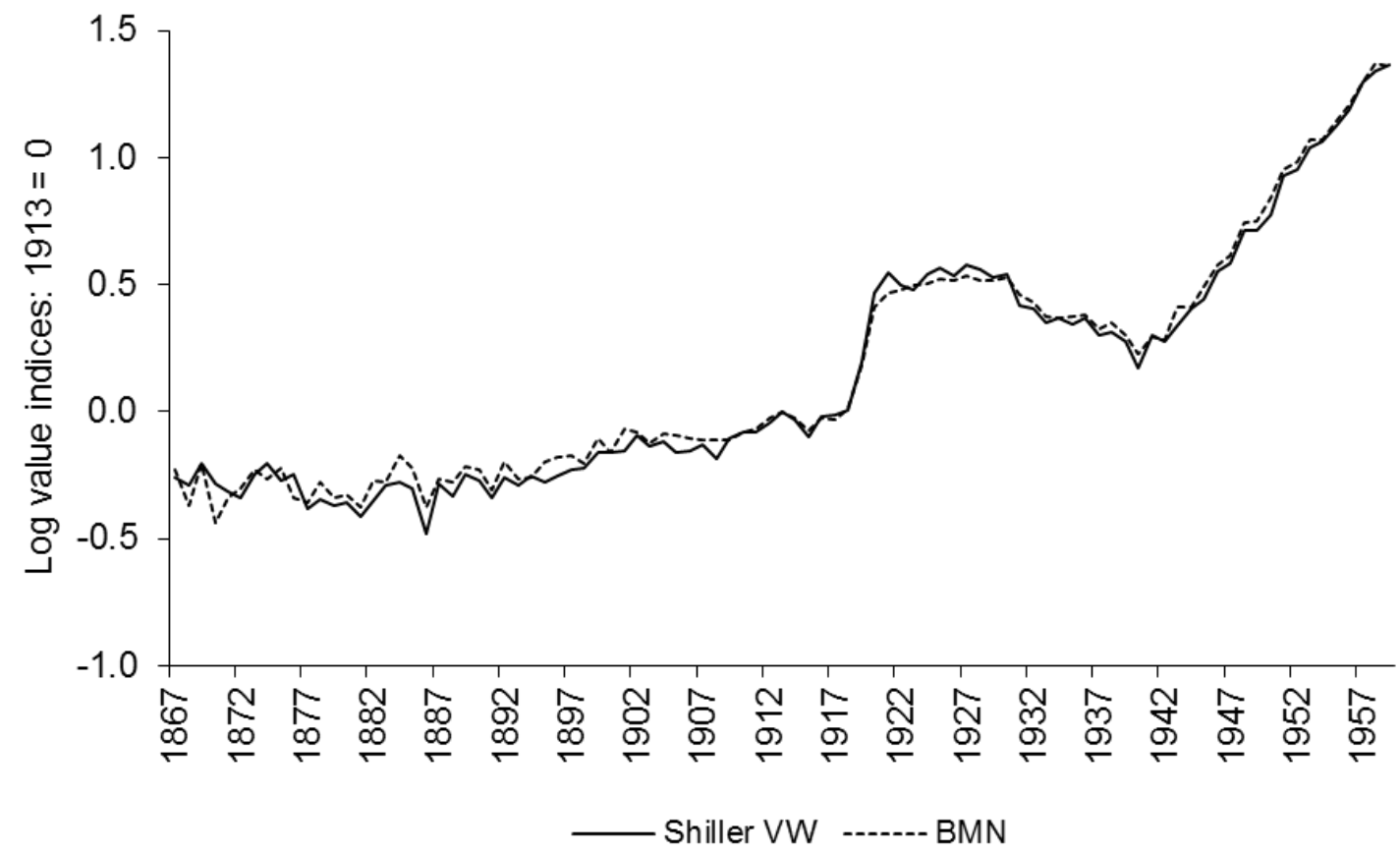

Figure A2: Size of confidence intervals around the estimated index

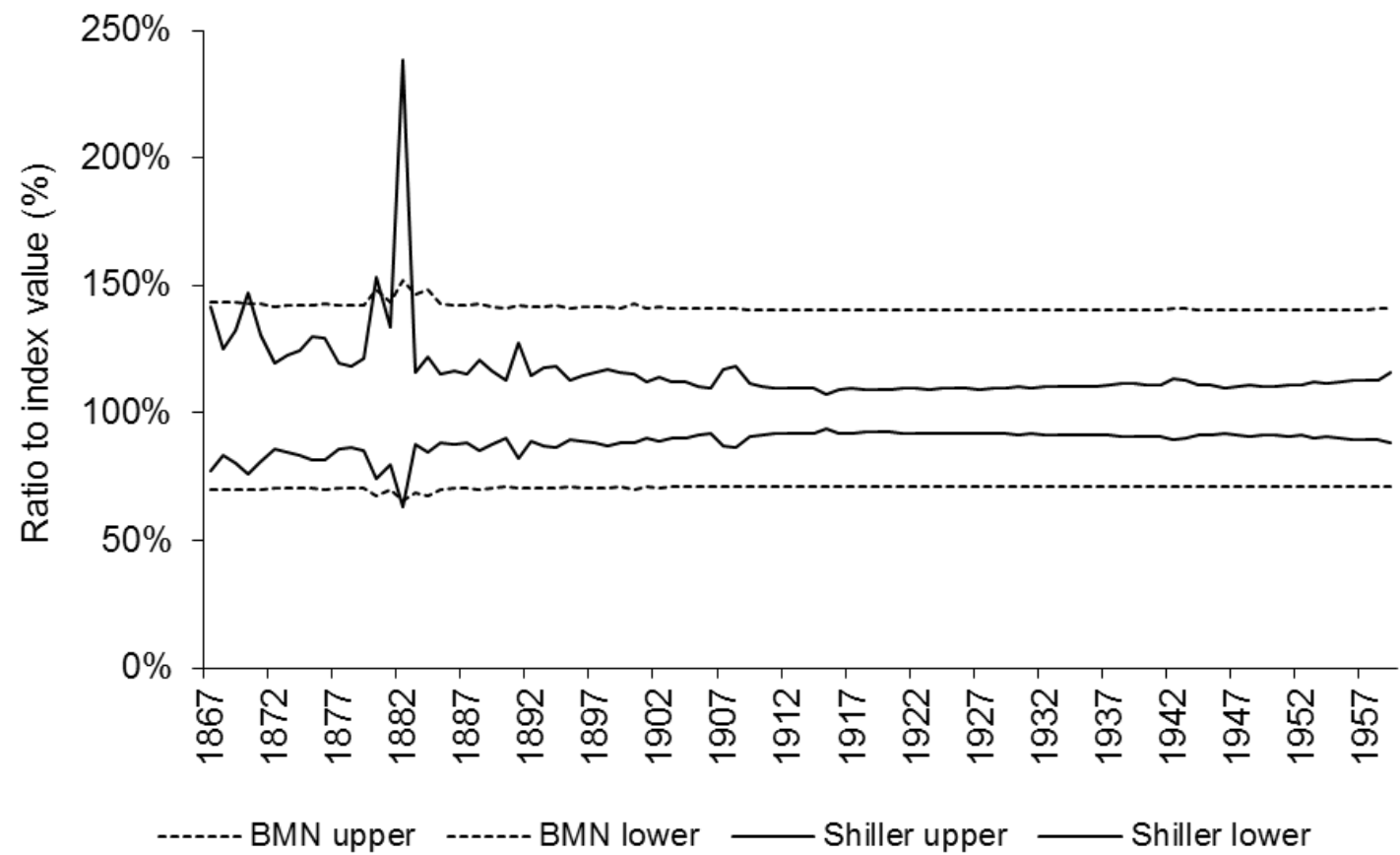

(C) 2010. This manuscript version is made available under the CC-BY-NC-ND 4.0 licence http://creativecommons.org/licenses/by-nc-nd/4.0/ 